\title{
Student Services Center (SSC): Upaya pembinaan prestasi, karir, dan kewirausahaan bagi mahasiswa melalui community based participatory research
}

\author{
Saiful Anwar ${ }^{1^{*}}$, \\ ${ }^{1}$ Institut Agama Islam Negeri (IAIN) Salatiga, Salatiga-Indonesia \\ $\left.{ }^{\star}\right)$ Korespondensi (e-mail: saifulanwarmieta@iainsalatiga.ac.id) \\ Received: 3-June-21; Revised: 10- June -21; Accepted: 26- June -21
}

\begin{abstract}
The purpo se of this service is to develop academic competence, non-acad emic competence, entrep reneurial competence and prepare the careers of students and alumni of the Islamic Economics and Business Faculty IAIN Salatiga. The service is carried out using a Community Based Participatory Research (CBPR) approach. Laying fo undation is done by analyzing the situation, reasons for choosing partners, conditions of assistance. partner engagement plans, and framing research questions for action plans. The tools us ed are community mapping in the hope of capturing the strengths, potentials, and issues that exist among students. Action plan s carried out by establishing the Students Service Center (SSC), Launching Students Service Center (SSC), developing student academic competencies through presentation skill training, debate competition mentoring/coaching, business plan mentoring/coaching, training in writing scientific papers, developing non-technical competencies student academics through futsal day and volleyball day, developing student entrepreneurship potential by mentoring millennial entrepreneurs, entrepreneurship talk shows, halal food festivals, student career development through advanced study seminars, scholarship interview mentoring, leadership talk shows, work simulations. The contribution of this research creates social changes in the research process and meaning ful results that can imp rove campus reputation through student ach ievement
\end{abstract}

Keywords: CBPR, SSC, Achievement

\begin{abstract}
Abstrak
Tujuan dari pengabdian ini adalah untuk mengembangkan kompetensi akademik, kompeten si non akademik, kompetensi kewirausahaan dan mempersiapkan karir mahasiswa dan alumni Fakultas Ekonomi dan Bisnis Islam IAIN Salatiga. Pengabdian dilakukan dengan pendekatan Community Based Participatory Research (CBPR). Laying foundation dilakukan dengan analisis situasi, alasan memilih mitra, kondisi dampingan. rencana pelibatan mitra, dan melakukan framing pertanyaan riset untuk rencana aksi. Tools yang digunakan yaitu mapping community dengan harapan dapat memotret kekuatan, potensi, dan isu-isu yang ada di kalangan mahasiswa. Rencana aksi yang dilakukan pendirian Students Service Centre (SSC), Launching SSC, pengembangan kompetensi akademik mahasiswa melalui presentation skill training, debate competition mentoring/coaching, bussiness plan mentoring/coaching, pelatihan penulisan Karya Tulis IImiah, pengembangan kompetensi non akademik mahasiswa melalui futsal day dan volley day, pengembangan potensi kewirausahaan mahasiswa dengan kegiatan pendampingan wirausaha millenial, entrepreneurship talkshow, halal food festival, pengembangan karir mahasiswa melalui advanced study seminar, mentoring wawancara beasiswa, talkshow leadhership, work simulation. Kontribusi penelitian ini menciptakan perubahan sosial pada research process dan meaningful results yang dapat meningkatkan reputasi kampus melalui prestasi mahasiswa.

Kata kunci: CBPR, SSC, Prestasi.

How to cite: Anwar, S. (2021). Student Services Center (SSC): Upaya pembinaan prestasi, karir, dan kewirausahaan bagi mahasiswa melalui community based participatory research. Penamas: Journal of Community Service, 1(1), 49-60.
\end{abstract}




\section{Pendahuluan}

Revolusi industri 4.0 menuntut mahasiswa tidak hanya menguasai hard skills sesuai kompetensi bidang ilmu yang ditekuni, tetapi juga mengusai soft skills yang dapat menunjang keberhasilan mereka di masa depan (Manara, 2014; Siswati, 2019). Dengan demikian mahasiswa atau lulusan dapat memiliki karakter unggul sesuai yang diharapkan sesuai dengan kebutuhan keterampilan abad 21. Hal tersebut dapat diwujudkan dengan dukungan penuh dari perguruan tinggi pada bidang kemahasiswaan. Wujud dari dukungan tersebut bisa berupa kelembagaan dalam bidang kemahasiswaan dan mendorong mahasiswa untuk meraih prestasi dalam berbagai kegiatan kejuaraan, melakukan persiapan karir, dan membina potensi kewirausahaan.

Era revolusi 4.0, pendidikan harus dapat menyikapi dan mengantisipasi perkembangan liberalisasi pasar kerja dan perkembangan masyarakat berbasis ilmu pengetahuan. Mobilitas mahasiswa dan tenaga kerja antar Negara juga memberikan tantangan bagi dunia pendidikan untuk melakukan komparasi mutu antar Negara. Prestasi dan kewirausahaan menjadi penting di era revolusi industri 4.0. Fakultas Ekonomi dan Bisnis Islam (FEBI) IAIN Salatiga adalah salah satu fakultas di IAIN Salatiga. FEBI IAIN Salatiga memiliki 4 program studi yaitu Perbankan Syariah S1, Ekonomi Syariah S1, Manajemen Bisnis Syariah dan Akuntansi Syariah S1. FEBI IAIN Salatiga memiliki visi "Menjadi Fakultas Ekonomi dan Bisnis Islam yang unggul dan menjadi rujukan di Indonesia dalam pendidikan, penelitian, dan pengabdian masyarakatyang damai bermartabatpada tahun 2029".

Visi tersebut diinternalisasikan dalam misi sebagai berikut, yaitu memberikan pelayanan yang mudah, ramah, cepat dan akurat, mengembangkan program studi sebagai centre of research ilmu-ilmu ekonomi dan bisnis Islam, memberikan layanan prima kepada mahasiswa dalam mengembangkan kemampuan akademik dan profesionalisme di bidang ekonomi dan bisnis Islam, menciptakan lulusan yang kompeten dan siap mengelola lembaga-lembaga ekonomi dan bisnis Islam sesuai dengan tuntutan pasar industry, menciptakan calon pelaku ekonomi dan bisnis Islam yang jujur, amanah dan menguasai ekonomi mikro dan makro juga ilmu- ilmu keislaman, menciptakan lulusan yang mampu mengembangkan ekonomi Islam yang dapat diterapkan kepada masyarakat, menjalin kerja sama dengan berbagai lembaga dalam skala regional, nasional dan asia tenggara di bidang pendidikan, penelitian, pengabdian masyarakat untuk menunjang pengembangan sumber daya, dan menyelenggarakan pemberdayaan ekonomi dan bisnis Islam dengan menerapkan nilai-nilai kearifan lokal.

Berdasarkan visi-misi di atas, FEBI IAIN Salatiga sudah seharusnya merancang program didasarkan pada visi-misi. Stressing visi FEBI adalah bagaimana menjadikan pendidikan, penelitian dan pengabdian masyarakat sebagai rujukan di Indonesia. FEBI IAIN Salatiga harus terus meningkatkan komitmen mutu dibidang pendidikan, penelitian dan pengabdian masyarakat agar sesuai dengan kebutuhan akademik, industri dan masyarakat. Namun saat ini Fakultas Ekonomi dan Bisnis 
Islam terkendala isu belum adanya unit pembantu bidang kemahasiswaan dan kerjasama dalam melakukan pembinaan prestasi, kewirausahaan, dan karir mahasiswa. Isu tersebut memberikan dampak tidak adanya pembinaan untuk mahasiswa dalam mengikuti kompetisi ilmiah maupun non ilmiah, tidak adanya pembinaan kewirausahaan mahasiswa sehingga bisnis mahasiswa tidak dapat sustainable, tidak adanya pembinaan persiapan kerja dan studi lanjut bagi calon lulusan untuk menunjang karir pasca kampus, dan tidak optimalnya web dan media sosial Fakultas Ekonomi dan Bisnis Islam dalam memberikan informasi kompetisi dan informasi lowongan pekerjaan sehingga membantu tugas Wakil Dekan III Bidang Kemahasiswaan dan Kerjasama. Informasi tersebut seharusnya segera diselesaikan sehingga Fakultas Ekonomi dan Bisnis Islam dapat menghasilkan sumber daya manusia yang unggul untuk menghadapi revolusi 4.0. Berikut adalah hasil dari pemahaman situasi dam pingan menggunakan tool mapping community

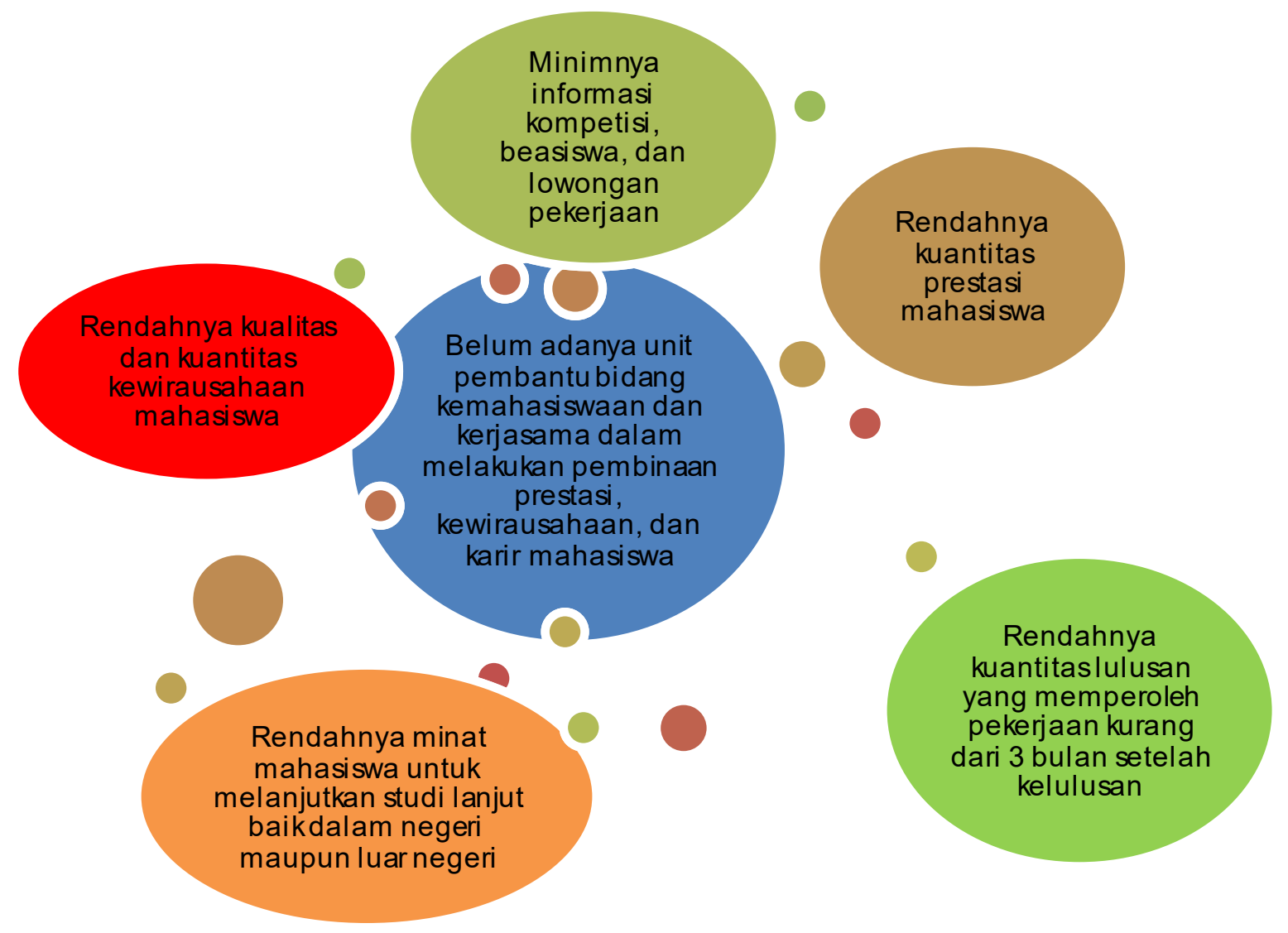

\section{Gambar 1. Mapping Community}

\section{Metode Pengabdian}

Community Based Participatory Research (CBPR) merupakan salah satu pendekatan penelitian berbasis komunitas untuk mengupayakan terwujudnya perubahan pembinaan mahasiswa di Fakultas Ekonomi dan Bisnis Islam dengan mengedepankan partisipasi aktif dari mahasiswa yang bersangkutan. Pengabdi sekaligus peneliti bersama mahasiswa terlibat aktif dalam setiap tahap penelitian termasuk dalam merumuskan desain penelitian, mengumpulkan data, menganalisis 
data, sampai desiminasi. Salah satu tujuan penggunaan metode ini adalah kebermanfaatan data untuk perubahan yang penekanannya berdasarkan research process dan meaningful results (Holkup et al., 2004; Tremblay et al., 2018). Langkah-langkah pengabdian yang dilakukan adalah sebagai berikut.

a. Laying foundations

Riset pengabdian dengan pendekatan Community Based Participatory Research (CBPR) diawali dengan Laying foundations (D'Alonzo, 2010). Peneliti melakukan inkulturasi dengan perangkat dan stakeholder kunci yang ada di Fakultas Ekonomi Dan Bisnis Islam IAIN salatiga. Fungsi dari tahapan ini adalah membangun kepercayaan bersama, membangun kesepahaman, komitmen bersama dan menentukan tim yang akan terlibat dalam kegiatan pengabdian. Hal ini perlu dilakukan karena dalam pendekatan ini subyek penelitian juga sebagai peneliti dan penghargaan atas local knowledge yang sudah ada (Schulz et al., 2011).

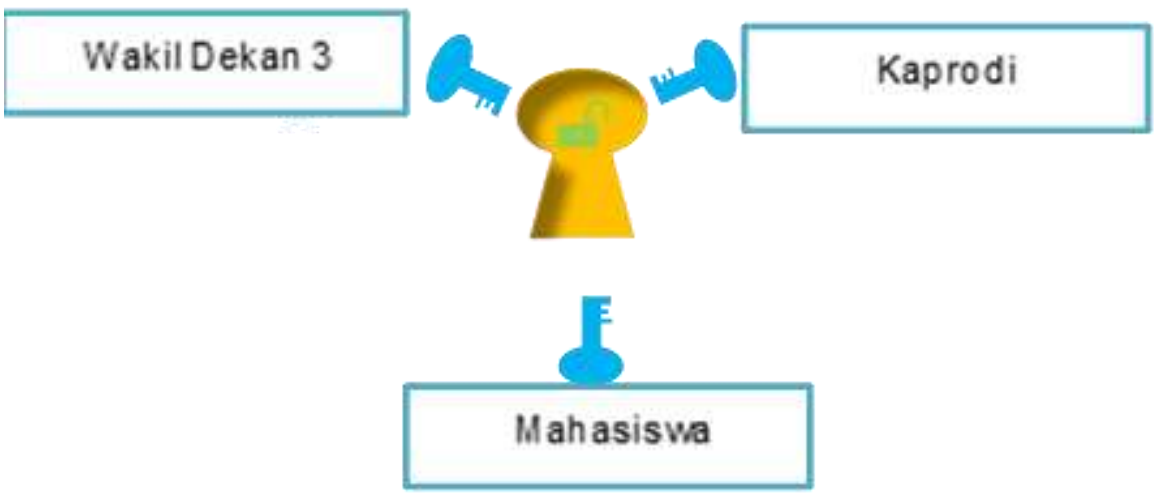

Gambar 2. Identifikasi Stakeholder Kunci

b. Planning

Pengembangan kompetensi mahasiswa harus dilakukan secara utuh dalam aspek kognitif, afektif, dan psikomotorik, serta dalam pengembangan kompetensi tersebut diperlukan berbagai upaya untuk meningkatkan kualitas mahasiswa. Untuk itu dilakukan Focus Group Discussion (FGD) untuk memperoleh kesepakatan agar tercipta model pengembangan kompetensi mahasiswa yang utuh (Barnack et al., 2013). Penentuan rencana aksi ini juga mempertimbangkan adanya aset sumber daya manusia. Selain itu dalam sesi ini peneliti bersamasama menentukan waktu sosialisasi dan aksi kegiatan.

\section{c. Information Gathering}

Tahapan ini yaitu pengumpulan data dengan menentukan fokus dan prioritas, kroscek landasan teori yang digunakan. Beberapa pertimbangan yang digunakan adalah mempertimbangkan luas dan kedalaman yang ingin dicapai, mengembangkan partisipan yang terlibat dan ukuran ketercapaian. 


\section{d. Action on finding}

Berdasarkan diskusi dengan sivitas akademika maka diperlukan sebuah unit yang bertugas untuk menyelasikan problematika hardskills mahasiswa Fakultas Ekonomi Dan Bisnis Islam IAIN Salatiga. Untuk itu dibentuklah unit Student Services Center. Unit ini membantu fakultas dalam memberikan inovasi pelayanan yang mudah, ramah, cepat dan akurat dan Memberikan layanan prima kepada mahasiswa dalam mengembangkan kemampuan akademik dan profesionalisme di bidang ekonomi dan bisnis Islam. Menciptakan lulusan yang kompeten dan siap mengelola lembaga-lembaga ekonomi dan bisnis Islam sesuai dengan tuntutan pasar industri, dan Menciptakan calon pelaku ekonomi dan bisnis Islam yang jujur, amanah dan menguasai ekonomi mikro dan makro juga ilmu- ilmu keislaman. Kegiatan disusun disesuaikan dengan kebutuhan dan target.

Menilik pada problema yang terjadi maka dirumuskan beberapa kegiatan utama yang disepakati dengan stakeholder kunci yaitu Pengembangan kompetensi akademik mahasiswa, Pengembangan kompetensi non akademik mahasiswa, Pengembangan kompetensi kewirausahaan mahasiswa dan Pengembangan karir mahasiswa. Tujuan dari kegiatan ini yaitu untuk meningkatkan pretasi mahasiswa baik akademik dan non akademik pada tingkat lokal maupun nasional, untuk meningkatkan jumlah mahasiswa yang berwirausaha di bidang industry halal, dan meningkatkan kesiapan mahasiswa dalam menghadapi dunia kerja.

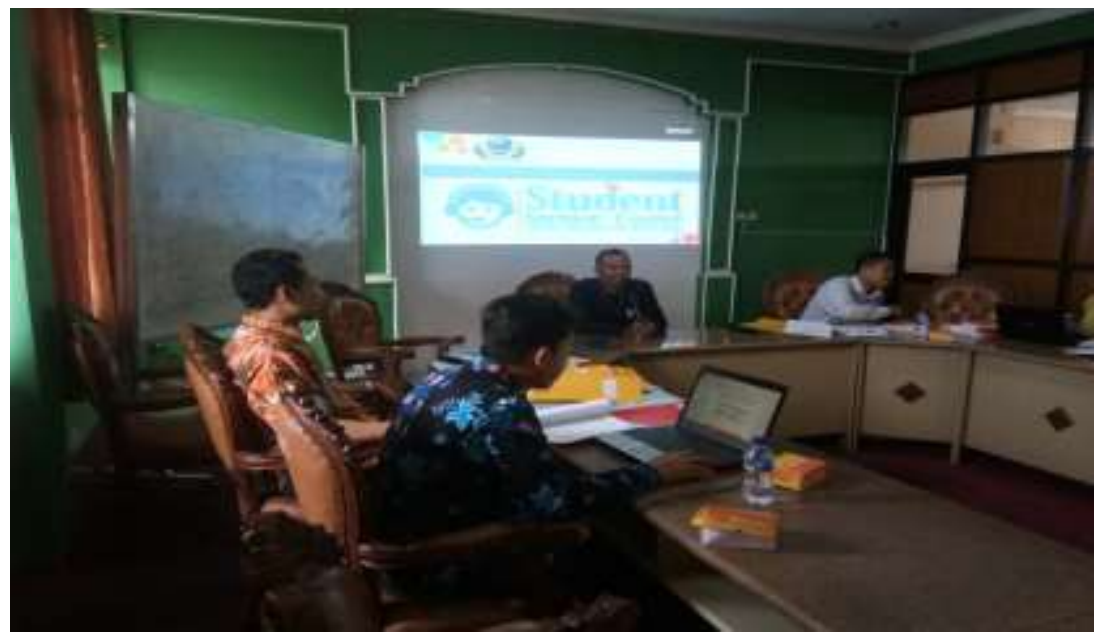

Gambar 3. Action on finding

e. Monev dan Evaluasi

Tahapan ini melakukan monitoring kegiatan pengabdian dengan mempertimbangkan indikator perubahan. Indicator perubahan yang digunakan sesuai dengan kesepakatan pada saat laying the foundations. 


\section{Hasil Pengabdian}

\section{Pengembangan Kompetensi Akademik Mahasiswa Debate Competition Mentoring/Coaching}

Salah satu kompetisi akademik yang menuntut wawasan yang luas, kemampuan berbahasa yang baik, dan kemampuan berargumentasi. Kemampuan bahasa yang baik akan meningkatkan kemampuan komunikasi mahasiswa dalam berinteraksi dengan masyarakat internasional, sedangkan kemahiran dalam berargumentasi akan meningkatkan kemampuan mahasiswa untuk mem buat keputusan berdasarkan analisis yang logis dan faktual.

Kompetisi debat merupakan upaya yang utuh dalam membangun $6 \mathrm{C}$, yaitu collaboration (kerjasama), creativity (kreatifitas), critical thinking (berfikir kritis), communication (berkomunikasi), citizenship (kewarganegaraan), dan character (karakter). Dalam kompetisi debat, secara berkesinambungan, beberapa unsur dalam $6 \mathrm{C}$ dibangun dan dikuatkan. Terutama, bobot tertingginya adalah membangun dan mengembangkan karakter dan kemampuan berpikir analitis dan kritis mahasiswa. Keleluasaan mahasiswa dalam mengolah informasi dan membuat keputusan yang rasional dan berterima sangat lekat dengan prinsip kemerdekaan dalam belajar.

Aktualisasi mahasiswa dalam kompetisi debat merupakan wujud dari kebijakan Kampus Merdeka. Mahasiswa mendapat kesem patan untuk menunjukkan sekaligus meningkatkan kemampuan akademis mereka melalui wahana kompetisi. Kegiatan debat telah lama menjadi kebutuhan dunia akademik mahasiswa. Tuntutan kompetensi penguasaan pengetahuan dan wawasan global menjadi salah satu alasan mengapa debat perlu menjadi bagian akademik mahasiswa. Kegiatan debat menuntut mahasiswa tidak hanya mampu mengungkapkan ide dalam bahasa Indonesia, tetapi juga menuntut mahasiswa mampu menguasai pengetahuan global, menganalisis, membuat judgement, dan meyakinkan publik.

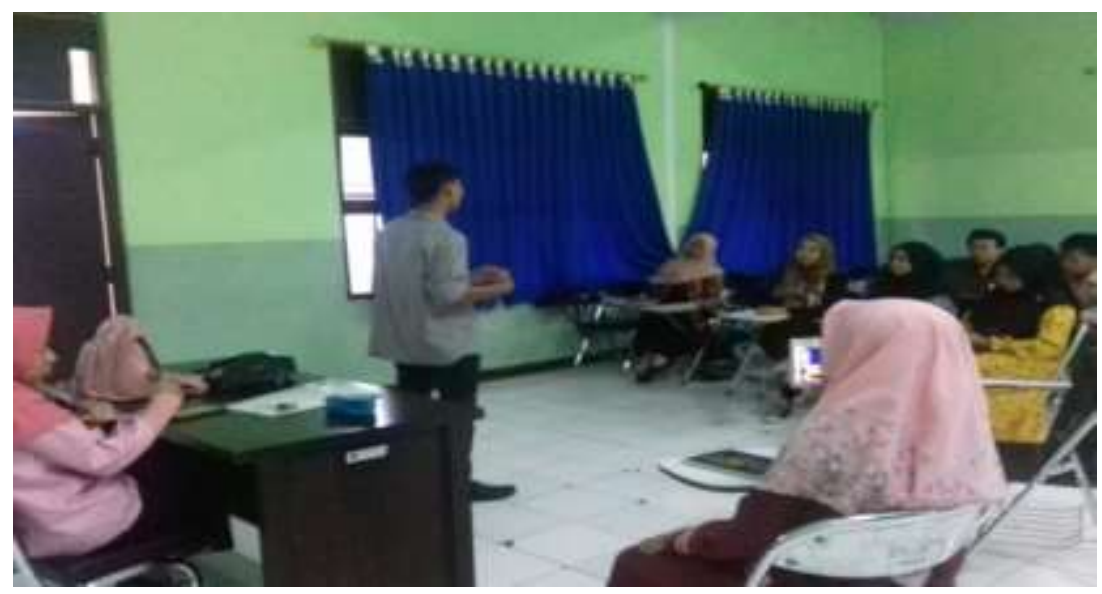

Gambar 4. Mentoring Debate Competition

Di dalam debat, mahasiswa akan dihadapkan pada persoalan-persoalan nyata yang dihadapi suatu masyarakat atau bangsa. Mahasiswa harus mampu 
menentukan posisi dan meyakinkan publik bahwa posisi mereka benar dan tepat. Oleh karena itu, debat merupakan media yang tepat dalam melatih kemampuan negosiasi dan argumentasi mahasiswa. Institusi pendidikan di Indonesia sudah selayaknya melaksanakan kompetisi debat antar mahasiswa dalam rangka internalisasi semangat kompetisi positif yang bemuatan tuntutan kemampuan komunikasi dan argumentasi. Sistem debat yang dikenalkan dalam mentoring ini adalah sistem parlemen asia dan sistem parlemen inggris. Model mentoring dilakukan setiap satu bulan sekali dan sesuai dengan jadwal kompetisi yang diikuti.

\section{Bussiness Plan Mentoring/Coaching}

Kompetisi business plan merupakan salah satu cara yang dapat mahasiswa gunakan untuk mengeksplorasi peluang bisnis yang ada di masyarakat demi menciptakan keberlanjutan ekonomi. Mahasiswa dituntut untuk menemukan beragam ide bisnis yang diciptakan dapat diimplementasikan ke dunia nyata. Pelatihan penyusunan business plan mendorong mahasiswa mengeksplorasi apa yang ditawarkan, siapa pembelinya, bagaimana cara menjualnya, berapa profitnya, berapa modal yang dibutuhkan, serta kapan modal akan berbalik kembali. Pada dasarnya, semua pertanyaan tersebut dapat terjawab secara lugas. Namun, solusi dari masalah bisnis tersebut harus dapat terjawab dengan motif ekonomi.

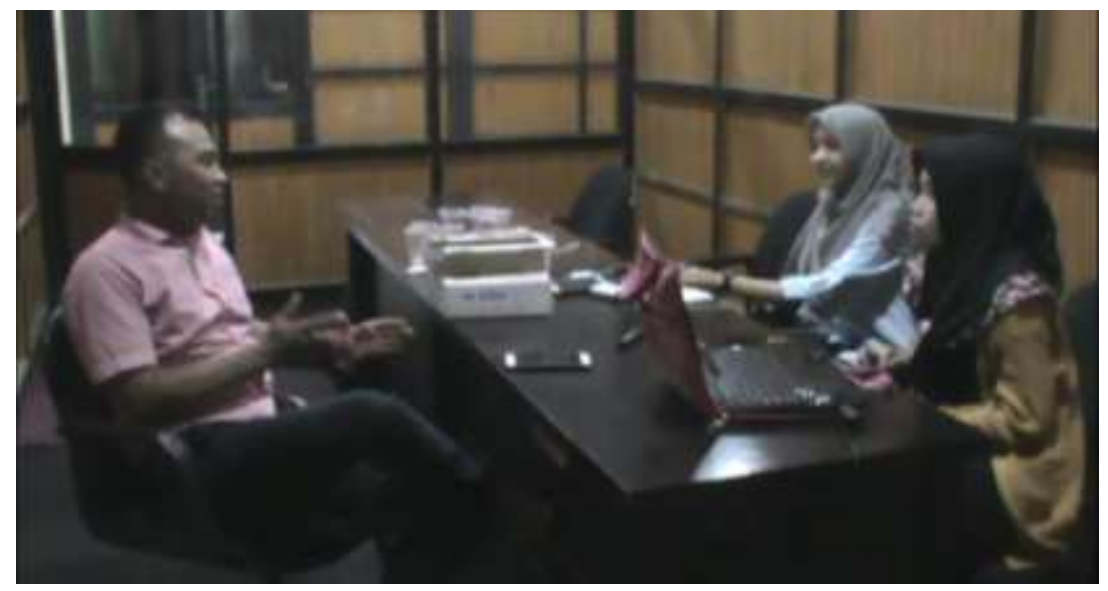

Gambar 5. Mentoring Persiapan Business Plan Competition

Bussiness Plan merupakan sebuah peta bagi calon entrepreneur menuju pembangunan bisnis yang sukses dan berkelanjutan Setiap entrepreneur yang sudah melakukan usaha atau akan membangun suatu usaha membutuhkan sebuah rencana bisnis yang baik dan berdasarkan fakta riil yang ada dilapangan guna meningkatkan peluang keberhasilan usahanya. Seringkali bisnis dikelola dengan hanya bermodalkan semangat, banyak orang yang ingin membangun suatu usaha tetapi tidak mau membuat rencana bisnis. Padahal tidak sedikit para pengusaha yang masih menghadapi kendala-kendala bahkan sampai gagal walaupun telah melakukan perencanaan bisnis, hal ini dikarenakan rencana bisnis yang ada tidak sepenuhnya menjadi pedoman operasi perusahaannya atau lemahnya sistem monitoring dan evaluasi selama bisnis itu berjalan. Pelatihan ini penting bagi mahasiswa karena sejatinya rencana bisnis harus fleksibel dan tidak menutup 
kemungkinan mengalami revisi dan pengembangan dibeberapa aspek ketika bisnis mengalami kendala dalam perjalanannya.

\section{Pelatihan Penulisan Karya Tulis IImiah}

Pelatihan ini dilaksanakan pada tanggal 5 Desember 2019. Karya tulis ilmiah merupakan kompetisi yang sering diselenggarakan oleh berbagai perguruan tinggi. Tujuan dari pelatihan ini yaitu untuk meningkatkan academic knowledge, skill of thinking, management skill, dan communication skill mahasiswa Fakultas Ekonomi dan Bisnis Islam. Kekurangan atas salah satu dari keempat keterampilan/kemahiran tersebut dapat menyebabkan berkurangnya jumlah prestasi mahasiswa dan secara jangka panjang terhadap mutu lulusan.

Kemampuan berpikir dan bertindak kreatif pada hakekatnya dapat dilakukan setiap manusia apalagi yang menikmati pendidikan tinggi. Kreativitas merupakan penjelmaan integratif dari tiga faktor utama dalam diri manusia, yaitu: pikiran (kognitif), perasaan (afektif), dan keterampilan (psikomotorik). Dalam faktor pikiran terdapat imajinasi, persepsi dan nalar. Faktor perasaan terdiri dari emosi, estetika dan harmonisasi. Sedangkan faktor keteram pilan mengandung bakat, faal tubuh dan pengalaman.

Pelatihan ini dikemas untuk mengasah kemampuan lulusan dalam kecepatan menemukan solusi atas persoalan yang dihadapinya. Dengan demikian, pemikiran dan perilaku yang ditunjukkan mahasiswa akan bersifat kreatif (unik dan bemanfaat) dan konstruktif (dapat diwujudkan). Perilaku tersebut dapat menjadi bekal dalam menghadapi kompetisi karya tulis ilmiah yang menuntut mahasiswa untuk memecahkan sebuah problem.

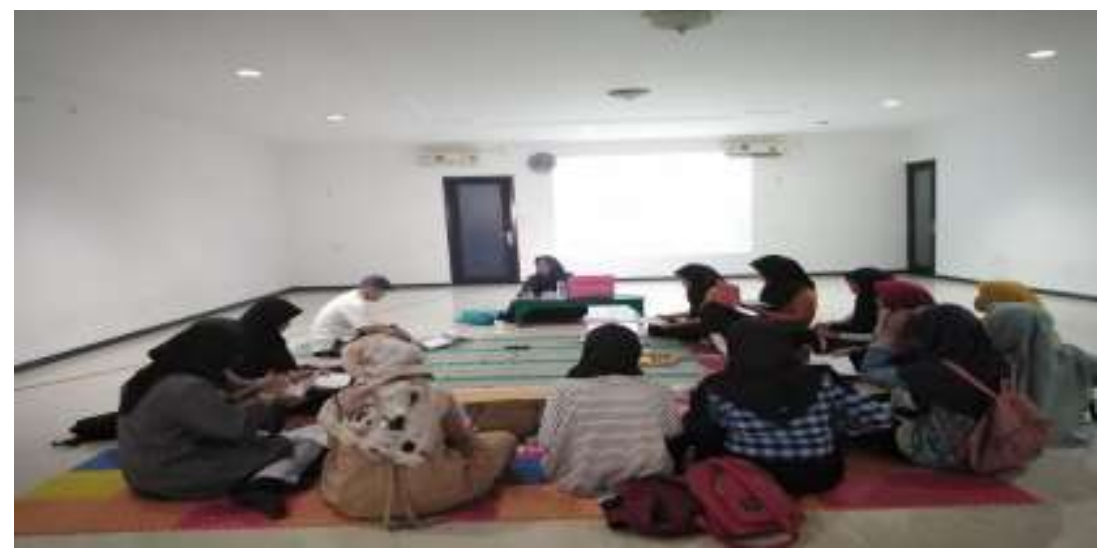

Gambar 6 Pelatihan Karya Tulis IImiah

\section{Pengembangan kompetensi non akademik mahasiswa: Presentation Skill Training}

Kegiatan ini dilaksanakan pada tanggal 28 November 201. Presentation skills dalam kegiatan ini diperuntukkan untuk kesiapan mahasiswa dalam menghadapi kompetisi karya tulis ilmiah, esai, dan bussines plan. Hal ini sangat penting mengingat berdasarkan evaluasi kompetisi mahasiswa selalu mengalami kegagalan ketika 
mencapai pada babak ini. Keterampilan presentasi sangat berguna baik di dalam maupun di luar kompetisi.

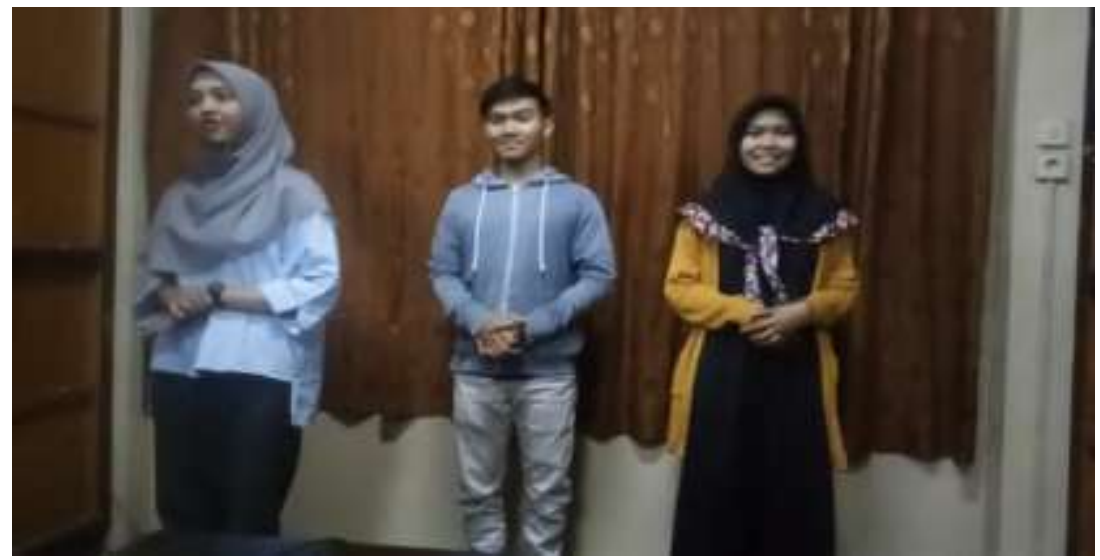

Gambar 7 Presentation Skill Training

Presentasi merupakan kesempatan yang menantang dan memperluas pemahaman mahasiswa. Dan di dunia kerja, seorang presenter yang percaya diri mampu menginformasikan dan membujuk rekan kerja secara efektif. Presentasi juga dapat membentuk bagian alami dari pembelajaran berbasis tugas. Dengan berfokus pada poin atau keterampilan bahasa tertentu, presentasi adalah cara yang sangat praktis untuk merevisi dan memperluas buku, berpasangan, dan kerja kelompok. Penonton juga dapat diberi tugas, misalnya serangkaian pertanyaan untuk dijawab pada presentasi, yang merupakan cara untuk membuat siswa saling mendengarkan

\section{Pengembangan Kompetensi Kewirausahaan Mahasiswa}

Mahasiswa menjadi bagian dari sumber daya manusia yang dapat menjadi tulang punggung pembangunan melalui kemandirian ekonomi bangsa. Mahasiswa juga merupakan bagian dari generasi milenial Indonesia. Mengutip riset dari IDN Research Institute tahun 2019, 69,1\% milenial di Indonesia memiliki minat untuk berwirausaha. Minat dan potensi wirausaha generasi milenial yang besar ini perlu didukung dan difasilitasi melalui tata kelola pendidikan tinggi yang mendukung program kewirausahaan mahasiswa di Fakultas Ekonomi dan Bisnis Islam.

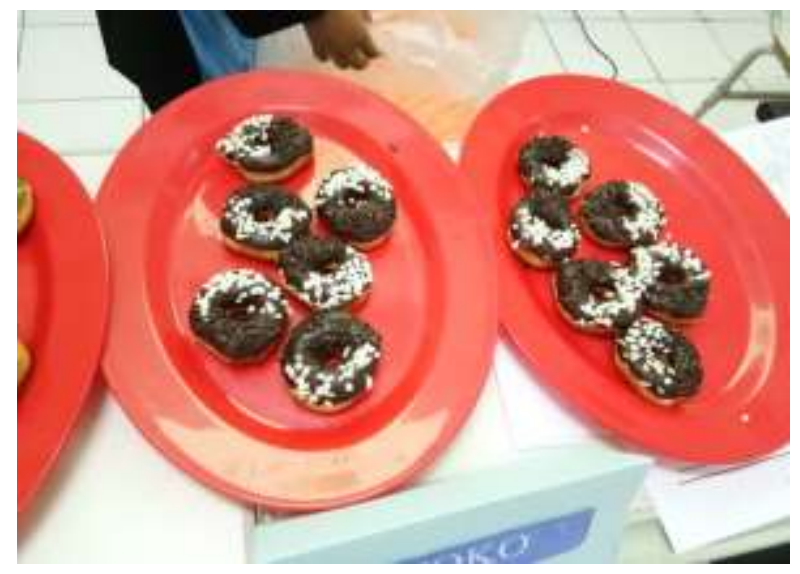

Gambar 8 Produk Bussines Plan

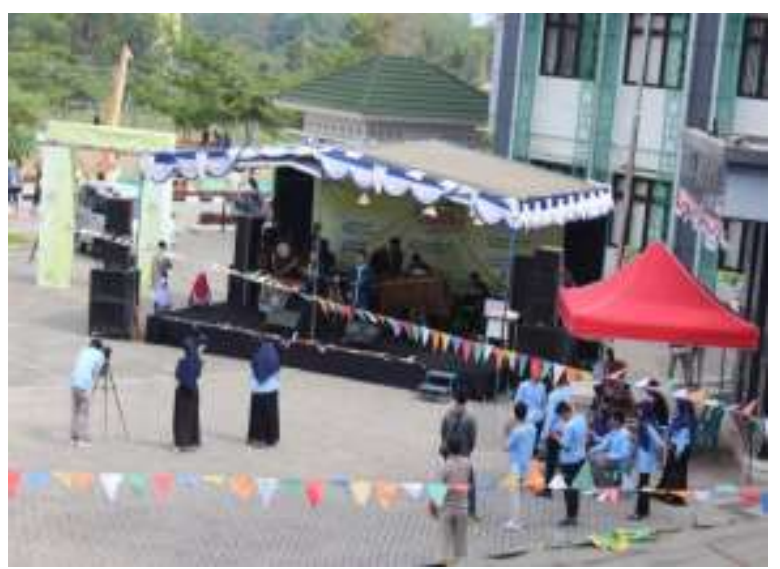

Gambar 9 Edukasi Halal Food 
Berdasarkan data tahun 2019, peringkat wirausaha Indonesia menempati 94 dari 137 Negara, dengan jumlah mencapai 3,5 persen dari jumlah penduduk. Rasio ini masih lebih rendah dibandingkan dengan negara lain seperti Malaysia 5 persen, China 10 persen, Singapura 7 persen, Jepang 11 persen maupun AS yang 12 persen. Fakultas Ekonomi dan Bisnis Islam memiliki peran penting untuk mendorong dan meningkatkan jumlah wirausaha muda di Indonesia. Oleh karena itu, lulusan perguruan tinggi itu harus disiapkan untuk menciptakan lapangan kerja bukan untuk sekedar meluluskan para pencari kerja.

Mahasiswa sebagai bagian dari generasi $Z$ terkenal memiliki kemampuan dan keahlian yang lebih melalui berbagai ide kreatif dan inovatif. Dalam berkontribusi serta berperan untuk ikut membangun perekonomian bangsa, para mahasiswa generasi milenial selama ini telah menelurkan berbagai entrepreneur muda yang sukses melalui berbagai usaha yang inovatif dengan memanfaatkan kemajuan teknologi. Harapannya kedepan dapat tumbuh beberapa usaha profesional yang muncul dari karya-karya kreatif dan inovatif para generasi millennial Fakultas Ekonomi dan Bisnis Islam, seperti Startup, Content Creator, berbagai macam produk makanan kekinian, jasa berbasis teknologi, bahkan sampai Youtuber, dan masih banyak lagi. Semua ini merupakan bentuk usaha yang dilakukan para mahasiswa atau generasi milenial untuk mencapai kesuksesan dan perlu terus didukung dan dikembangkan.

\section{Pengembangan Karir Mahasiswa}

Kegiatan ini dilaksanakan pada tanggal 17 Desember 2019. Bimbingan Karier adalah bimbingan dalam mempersiapkan diri menghadapi dunia kerja, dalam memilih lapangan kerja atau jabatan atau profesi tertentu serta membekali diri supaya siap memangku jabatan itu, dan dalam menyesuaikan diri dengan berbagai tuntutan dari lapangan pekerjaan yang dimasuki (Pasmawati, 2018). Bimbingan karier juga dapat

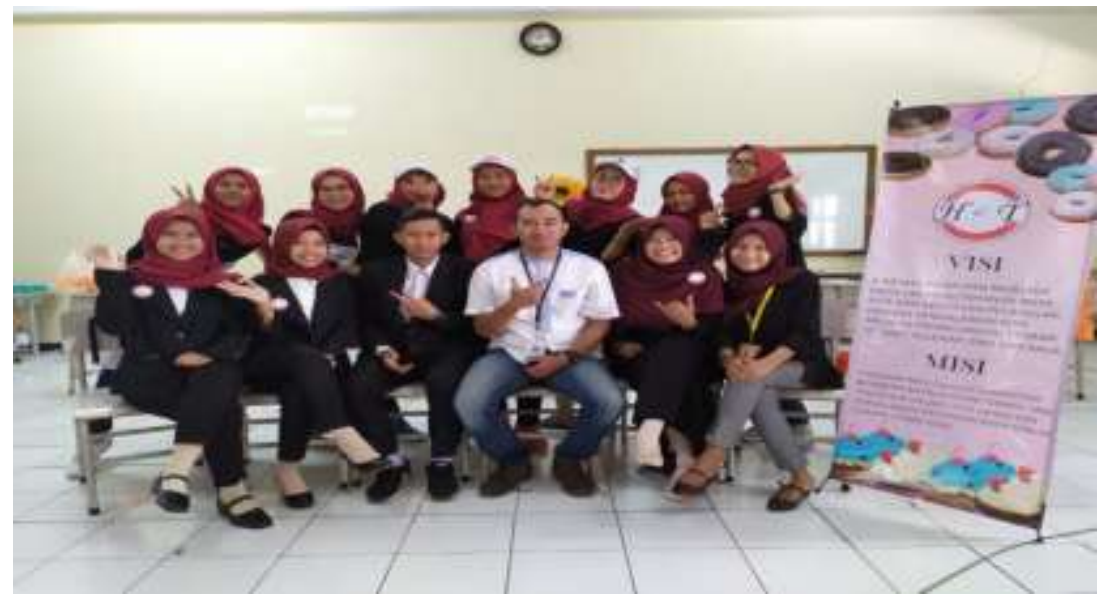

Gambar 10 Work Simulation

dipakai sebagai sarana pemenuhan kebutuhan perkembangan individu yang harus dilihat sebagai bagian integral dari program pendidikan yang diintegrasikan dalam setiap pengalaman belajar bidang studi. Salah satu kegiatan yang dilakukan yaitu 
work simulation. Kegiatan ini mengawali model bimbingan karir di fakultas ekonomi dan bisnis islam iain salatiga. Beberapa kegiatan yang direncanakan kemudian yaitu sosialisasi beasiswa magister, pelatihan wawancara kerja, pelatihan wawancara beasiswa, pelatihan pembuatan curriculum vitae.

\section{Monev dan evaluasi}

Pengabdian ini bertujuan untuk mengembangkan kompetensi akademik, kompetensi non akademik, kompetensi kewirausahaan dan mempersiapkan karir mahasiswa dan alumni Fakultas Ekonomi dan Bisnis Islam IAIN Salatiga. Salah satu ukuran yang ditentukan adalah jumlah prestasi mahasiswa. Setidaknya setelah keberadaan Student Service Center, mahasiswa Fakultas Ekonomi dan Bisnis Islam IAIN Salatiga meraih juara 1 sebanyak 3 kali, juara 2 sebanyak 1 kali dan harapan 1 tiga kali pada kompetisi debat nasional. Selain itu juga terdapat mahasiswa menjadi best speakers pada kompetisi debat ekonomi nasional sebanyak 3 kali. Juara 1 lomba karya tulis ilmiah tingkat nasional sebanyak 3 kali, menjadi juara 3 dalam penyusunan business plan tingkat nasional dan santripreneur terbaik. Ini merupakan bentuk kontribusi pengabdian yang perlu untuk dijaga keberlanjutannya. Berdasarkan evaluasi beberapa kegiatan tentang kompetensi non akademik dan kewirausahaan belum dapat diukur ketercapaiannya. Kedepan perlu untuk mengembangkan indikator ketercapaian kewirausahaan dan karir sehingga dapat memberikan dukungan pada akreditasi.

\section{Kesimpulan}

Kegiatan ini telah terbukti berhasil mengembangkan kompetensi akademik, kompetensi non akademik, kompetensi kewirausahaan dan mempersiapkan karir mahasiswa dan alumni Fakultas Ekonomi dan Bisnis Islam IAIN Salatiga. Kegiatan ini sekaligus memberikan manfaat terhadap pencapaian visi-misi Fakultas Ekonomi dan Bisnis Islam IAIN Salatiga yaitu untuk memberikan pelayanan yang mudah, ramah, cepat dan akurat, Memberikan layanan prima kepada mahasiswa dalam mengembangkan kemampuan akademik dan profesionalisme di bidang ekonomi dan bisnis Islam, Menciptakan lulusan yang kompeten dan siap mengelola lembagalembaga ekonomi dan bisnis Islam sesuai dengan tuntutan pasar industri, dan Menciptakan calon pelaku ekonomi dan bisnis Islam yang jujur, amanah dan menguasai ekonomi mikro dan makro juga ilmu-ilmu keislaman.

\section{Ucapan Terimakasih}

Terima kasih peneliti sampaikan kepada pengelola Fakultas Ekonomi Dan Bisnis Islam IAIN Salatiga atas kesediaanya menjadi tempat pengabdian.

\section{Referensi}

Barnack-Tavlaris, J. L., Garcini, L., Sanchez, O., Hernandez, I., \& Navarro, A. M. (2013). Focus group discussions in community-based participatory research to inform the development of a human papillomavirus (HPV) educational intervention for Latinas in San Diego. Journal of Cancer Education: The Official 
Journal of the American Association for Cancer Education, 28(4), 784-789. https://doi.org/10.1007/s13187-013-0516-7

D'Alonzo, K. T. (2010). Getting started in CBPR: lessons in building community partnerships for new researchers. Nursing Inquiry, 17(4), 282-288. https://doi.org/10.1111/j.1440-1800.2010.00510.x

Holkup, P. A., Tripp-Reimer, T., Salois, E. M., \& Weinert, C. (2004). Communitybased participatory research: an approach to intervention research with a Native American community. ANS. Advances in Nursing Science, 27(3), 162-175. https://doi.org/10.1097/00012272-200407000-00002

Manara, M. U. (2014). Hard Skills dan Soft Skills pada Bagian Sumber Daya Manusia di Organisasi Industri. Jurnal Psikologi Tabularasa, 9(1), 34-47.

Pasmawati, H. (2018). Urgensi Bimbingan Karier di Perguruan Tinggi Untuk membantu Kesiapan mahasiwa Tahun Akhir Memasuki Dunia Kerja. Jurnal IImiah

Syi'ar, 18(1),

$1-12$. https://doi.org/http://dx.doi.org/10.29300/syr.v18i1.1243

Schulz, A. J., Israel, B. A., Coombe, C. M., Gaines, C., Reyes, A. G., Rowe, Z., ... Weir, S. (2011). A community-based participatory planning process and multilevel intervention design: toward eliminating cardiovascular health inequities. Health Promotion Practice, 12(6), 900-911. https://doi.org/10.1177/1524839909359156

Siswati, S. (2019). Pengembangan Soft Skills dalam Kurikulum untuk Menghadapi Revolusi Industri 4.0. Edukasi: Jurnal Pendidikan, 17(2), 264-273.

Tremblay, M.-C., Martin, D. H., McComber, A. M., McGregor, A., \& Macaulay, A. C. (2018). Understanding community-based participatory research through a social movement framework: a case study of the Kahnawake Schools Diabetes Prevention Project. BMC Public Health, 18(1), 487. https://doi.org/10.1186/s12889-018-5412-y 